\title{
Uji Aktivitas Ekstrak Etanol Daun Kersen \\ (Muntingia calabura L.) Sebagai Inhibitor Enzim $\alpha$-Glukosidase Dengan Menggunakan Elisa Reader
}

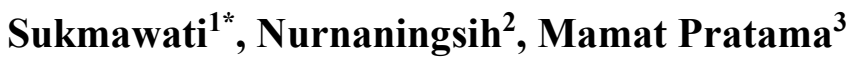 \\ ${ }^{123}$ Fakultas Farmasi, Universitas Muslim Indonesia
}

\begin{tabular}{|c|c|}
\hline Article info & Abstract \\
\hline History & Cherry leaves (Muntingia calabura L) contain metabolite compounds such \\
\hline Submission: 01-05-2019 & as alkaloids, antrakinons,polyphenols, tannins, saponins and are rich in \\
\hline Review: $15-02-20120$ & flavonoid components such as flavones, flavanones, flavans and biflavants \\
\hline Accepted: 13-07-2020 & which have antidiabetic activity. According to research conducted by \\
\hline $\begin{array}{l}\text { "Email: } \\
\text { sukmawati.syarif@umi.ac.id }\end{array}$ & $\begin{array}{l}\text { Apriyanti(2016) showed ethanol extract of cherry leaves (Muntingia } \\
\text { calabura } L \text { ) at a dose of } 250 \mathrm{mg} / \mathrm{BW} \text { can significantly reduce blood glucose }\end{array}$ \\
\hline DOI: $10.33096 /$ jffi.v7i2.506 & $\begin{array}{l}\text { ethanol extract of cherry leaves (Muntingia calabura L) as an } \alpha \text {-glucosidase } \\
\text { enzyme inhibitor using ELISA reader. The method was divided into } 3\end{array}$ \\
\hline Keywords: & groups, group 1 (extract sample), group 2 (blank) and group 3 (rootbose). \\
\hline Muntingia calabura L.; Cherry & Each group added $25 \mu L$-glucosidase solution $(0.25$ units $/ m L$ then \\
\hline $\begin{array}{l}\text { leaves; } \alpha \text {-glucosidase enzyme } \\
\text { inhibitors }\end{array}$ & $\begin{array}{l}\text { measured using a } 405 \mathrm{~nm} \text { ELISA reader. The results showed that ethanol } \\
\text { extract of cherry leaves KgBW (Muntingia calabura L) had activity as an } \alpha \text { - } \\
\text { glucosidase inhibitor with IC50 } 34,197 \mu \mathrm{g} / \mathrm{mL} \text { and can be categorized as } \\
\text { active. }\end{array}$ \\
\hline
\end{tabular}

\section{Pendahuluan}

Keanekaragaman hayati yang dimiliki Indonesia merupakan hal yang sangat potensial dalam mengembangkan obat herbal yang berbasis pada tumbuhan. Lebih dari 1000 spesies tumbuhan dapat dimanfaatkan sebagai bahan baku obat. Tumbuhan tersebut menghasilkan metabolit sekunder yang struktur molekul dan aktivitas biologik yang beranekaragam sehingga berpotensi untuk dikembangkan menjadi obat berbagai penyakit (Hikmal, Alam, G, \& Mufidah 2015).

Salah satu tumbuhan yang dapat digunakan sebagai obat adalah kersen. Daun kersen dapat direbus atau direndam dalam air yang berkhasiat dalam pengobatan berbagai penyakit seperti mengurangi pembengkakan kelenjar prostat, sebagai obat untuk menurunkan panas, menghilangkan sakit kepala, flu dan mengobati penyakit asam urat, selain itu juga dapat dimanfaatkan sebagai antiseptik, antioksidan, antimikroba, antiinflamasi, antidiabetes dan antitumor. Bagian daun tumbuhan kersen kaya akan komponen flavonoid seperti flavon, flavanon, flavan dan biflavan yang memiliki aktivitas antidiabetes dan sitotoksik (Arum, Supartono, \& Sudarmin 2012). Ekstrak etanol daun kersen mengandung alkaloid, antrakinon, polifenol, tanin, saponin dan flavonoid (Krishnaveni, M \& Dhanalaksmi, R 2014).

Menurut Apriyanti (2016), ekstrak etanol daun kersen (Muntingia calabura L) dengan dosis $250 \mathrm{mg} / \mathrm{kg}$ berat badan secara signifikan dapat menurunkan kadar glukosa darah pada tikus putih jantan galur wistar. Namun pada penelitian tersebut masih belum diketahui mekanisme yang spesifik untuk penurunan kadar glukosa darah, sehingga perlu dilakukan penelitian untuk menguji lebih lanjut penurunan kadar glukosa darah secara in vitro dengan mekanisme penghambatan alfa-glukosidase. Aktivitas enzim $\alpha$-glukosidase seperti maltase dan sukrase dalam menghidrolisis oligosakarida menjadi glukosa, fruktosa dan monosakarida lain pada dinding usus halus dapat dihambat oleh senyawa obat inhibitor $\alpha$ glukosidase. Penghambatan aktivitas enzim ini efektif dalam mengurangi pencernaan karbohidrat dan proses absorpsinya dalam usus halus sehingga dapat menurunkan kadar glukosa darah post prandial penderita diabetes melitus (Rais, IRidwan, et al 2013).

Berdasarkan hal tersebut akan dilakukan penelitian uji aktivitas ekstrak etanol daun kersen (Muntingia calabura L) sebagai inhibitor enzim $\alpha-$ glukosidase untuk pengobatan diabetes melitus.

\section{Metode Penelitian}

\section{II.1 Pengambilan dan Pengolahan sampel}

Sampel penelitian adalah daun kersen (Muntingia calabura L.) yang diperoleh dari Kecamatan Paleteang, Kabupaten Pinrang Provinsi Sulawesi Selatan. Daun kersen (Muntingia calabura L.) yang telah diperoleh dicuci bersih dari kotoran yang melekat dengan menggunakan air mengalir setelah itu dipotong kecil-kecil. Kemudian 
dikeringkan dengan cara di angin-anginkan, lalu di serbukkan.

\section{II.2 Ekstraksi}

Sampel berupa serbuk daun kersen (Muntingia calabura L.) ditimbang $50 \mathrm{~g}$ dimasukkan kedalam wadah maserasi, lalu ditambahkan $750 \mathrm{~mL}$ pelarut etanol $96 \%$, dibiarkan selama 3 hari dalam bejana tertutup dan terlindung dari cahaya matahari langsung sambil diaduk secara periodik, setelah 3 x 24 jam dilakukan penyaringan dan ampasnya dimaserasi kembali dengan $750 \mathrm{~mL}$ etanol. Remaserasi dilakukan sebanyak 2 kali selama $\pm 2 \times 24$ jam. Ekstrak hasil maserasi atau filtrat yang dihasilkan ditampung menjadi satu dan diuapkan hingga diperoleh ekstrak etanol kental.

\section{II.3 Uji Aktivitas Inhibitor Enzim $\alpha$-Glukosidase}

Uji aktivitas inhibitor enzim $\alpha$-glukosidase dilakukan dengan beberapa modifikasi (Febrinda, AEarly, Astawan, M, Wesdiyati, T, \& Yuliana, NDewi 2013):

\section{Pembuatan Larutan Sampel Ekstrak Etanol Daun Kersen (Muntingia calabura L.)}

Pembuatan larutan induk 1000 ppm. Ekstrak etanol daun kersen (Muntingia calabura L.) ditimbang $50 \mathrm{mg}$, kemudian dimasukkan kedalam labu ukur $50 \mathrm{~mL}$. Untuk membuat larutan dengan konsentrasi 1000 ppm, kemudian ditambahkan $5 \mu \mathrm{L}$ DMSO, kemudian ditambahkan buffer fosfat $\mathrm{pH} 7$ sampai tanda batas, sehingga diperoleh konsentrasi $1000 \mathrm{ppm}$. Selanjutnya dibuat seri konsentrasi 50 ppm, 100 ppm, 150 ppm, 200 ppm, dan 250 ppm dengan memipet masing-masing $250 \mu \mathrm{L}, 500 \mu \mathrm{L}$, $750 \mu \mathrm{L}, \quad 1000 \mu \mathrm{L}$, dan $1250 \mu \mathrm{L}$ kemudian dimasukkan dalam labu ukur $5 \mathrm{~mL}$ dan dicukupkan volumenya sampai tanda batas.

\section{Pembuatan larutan pembanding akarbose}

Akarbose sebanyak $5 \mathrm{mg}$ dimasukkan kedalam labu ukur $5 \mathrm{~mL}$ untuk membuat larutan stok dengan konsentrasi 1000 ppm, kemudian ditambahkan $5 \mu \mathrm{L}$ DMSO, kemudian ditambahkan dapar fosfat $0,1 \mathrm{M}(\mathrm{pH} 7,0)$ sampai tanda batas. Selanjutnya dibuat seri konsentrasi 50 ppm, 100 ppm, $150 \mathrm{ppm}, 200 \mathrm{ppm}$ dan $250 \mathrm{ppm}$ dengan memipet masing-masing $250 \mu \mathrm{L}, 500 \mu \mathrm{L}, 750 \mu \mathrm{L}$, 1000 ppm dan $1250 \mu \mathrm{L}$ dari larutan stok kemudian dimasukkan dalam labu ukur $5 \mathrm{~mL}$ kemudian dicukupkan volumenya hingga tanda batas.

\section{Penyiapan larutan enzim $\alpha$-glukosidase $(0,25$ $U / m L)$}

Enzim $\alpha$-glukosidase ditimbang sebanyak 1 mg kemudian dilarutkan dengan dapar fosfat ( $\mathrm{pH} 7)$ sebanyak $1 \mathrm{~mL}$ (28 U/mL). Kemudian dibuat larutan enzim $\alpha$-glukosidase dengan konsentrasi $0,25 \mathrm{U} / \mathrm{mL}$, dengan cara memipet $89,28 \mu \mathrm{L}$ lalu dicukupkan volumenya dengan dapar fosfat $(\mathrm{pH} 7)$ sebanyak 10 $\mathrm{mL}$.

\section{Penyiapan substrat p-nitrofenil- $\alpha-D$ - glukopiranosida (PNPG) $5 \mathrm{mM}$}

Substrat p-nitrofenil- $\alpha$-D-glukopiranosida (PNPG) ditimbang sebanyak 15,062 mg, kemudian dilarutkan dengan dapar fosfat $(\mathrm{pH} 7)$ sebanyak 10 $\mathrm{mL}$ sehingga didapatkan konsentrasi substrat PNPG $5 \mathrm{mM}$.

\section{Pengujian Blanko}

Masing-masing campuran pereaksi yang digunakan dalam uji ini mengandung $10 \mu \mathrm{L}$ dimetilsulfoksida (DMSO) ditambah $50 \mu \mathrm{L}$ dapar fosfat $0,1 \mathrm{M}(\mathrm{pH} 7,0)$ dan $25 \mu \mathrm{L}$-nitrofenil $\alpha$-Dglukopiranosida (PNPG) $5 \mathrm{mM}$, kemudian ditambahkan $25 \mu \mathrm{L}$ larutan $\alpha$-glukosidase $(0.25$ $\mathrm{U} / \mathrm{mL}$ ) lalu diinkubasi selama 30 menit pada suhu $37^{\circ} \mathrm{C}$. Reaksi dihentikan dengan menambahkan 100 $\mu \mathrm{L}$ larutan natrium karbonat $0.2 \mathrm{M}$. Sampel diukur serapannya dengan ELISA reader pada panjang gelombang $405 \mathrm{~nm}$ (Febriyani, V 2014).

\section{Pengujian kontrol blanko}

Masing-masing campuran pereaksi yang digunakan dalam uji ini mengandung $10 \mu \mathrm{L}$ dimetilsulfoksida (DMSO) ditambah $50 \mu \mathrm{L}$ dapar fosfat $0,1 \mathrm{M}(\mathrm{pH} 7,0)$ dan $25 \mu \mathrm{L}$-nitrofenil $\alpha$-Dglukopiranosida (PNPG) $5 \mathrm{mM}$, kemudian ditambahkan $25 \mu \mathrm{L}$ dapar fosfat $(\mathrm{pH}$ 7) lalu diinkubasi selama 30 menit pada suhu $37^{\circ} \mathrm{C}$. Reaksi dihentikan dengan menambahkan $100 \mu \mathrm{L}$ larutan natrium karbonat $0.2 \mathrm{M}$. Sampel diukur serapannya dengan ELISA reader pada panjang gelombang 405 nm (Sukmawati et al 2019).

\section{Pengujian pembanding akarbose}

Masing-masing campuran pereaksi yang digunakan dalam uji ini mengandung $10 \mu \mathrm{L}$ larutan akarbose dari masing-masing seri konsentrasi yang telah dibuat yaitu $50 \mathrm{ppm}, 150 \mathrm{ppm}$, dan $250 \mathrm{ppm}$ ditambah $50 \mu \mathrm{L}$ dapar fosfat $0,1 \mathrm{M}(\mathrm{pH} 7,0)$ dan 25 $\mu \mathrm{L}$ p-nitrofenil $\alpha$-D-glukopiranosida (pNPG) 0.5 mM. Kedalam sampel ditambahkan $25 \mu \mathrm{L}$ larutan $\alpha-$ glukosidase $(0.25$ unit $/ \mathrm{mL})$ lalu diinkubasi selama 30 menit pada suhu $37^{\circ} \mathrm{C}$. Reaksi dihentikan dengan menambahkan $100 \mu \mathrm{L}$ larutan natrium karbonat 0.2 M. Pembanding akarbose diukur serapannya dengan ELISA reader pada panjang gelombang 405 nm.

\section{Pengujian kontrol pembanding akarbose}

Masing-masing campuran pereaksi yang digunakan dalam uji ini mengandung $10 \mu \mathrm{L}$ larutan akarbose dari masing-masing seri konsentrasi yang telah dibuat yaitu $50 \mathrm{ppm}, 100 \mathrm{ppm}, 150 \mathrm{ppm}, 200$ ppm dan $250 \mathrm{ppm}$ ditambah $50 \mu \mathrm{L}$ dapar fosfat 0,1 $\mathrm{M}(\mathrm{pH} 7,0)$ dan $25 \mu \mathrm{L}$ p-nitrofenil $\alpha$-Dglukopiranosida (pNPG) $0.5 \mathrm{mM}$ lalu diinkubasi selama 30 menit pada suhu $37^{\circ} \mathrm{C}$. Reaksi dihentikan dengan menambahkan $100 \mu \mathrm{L}$ larutan natrium karbonat $0.2 \mathrm{M}$. Blanko pembanding akarbose diukur serapannya dengan ELISA reader pada panjang gelombang $405 \mathrm{~nm}$. 


\section{Pengujian sampel ekstrak etanol daun kersen (Muntingia calabura L.)}

Untuk pengujian sampel ekstrak etanol daun kersen (Muntingia calabura L.) sebanyak 50 $\mu \mathrm{L}$ dapar fosfat ( $\mathrm{pH} 7$ ), kemudian ditambahkan 25 $\mu \mathrm{L}$ PNPG $(5 \mathrm{mM})$, lalu ditambahkan $10 \mu \mathrm{L}$ larutan sampel dari masing-masing seri konsentrasi yang telah dibuat yaitu $50 \mathrm{ppm}, 100 \mathrm{ppm}, 150 \mathrm{ppm}, 200$ ppm, dan $250 \mathrm{ppm}$. Kemudian kedalam sampel ditambahkan $25 \mu \mathrm{L}$ larutan enzim $\alpha$-glukosidase $(0,25 \mathrm{U} / \mathrm{mL})$, lalu diinkubasi selama 30 menit pada suhu $37^{\circ} \mathrm{C}$. Reaksi dihentikan dengan menambahkan $100 \mu \mathrm{L}$ larutan natrium karbonat 0,2 M. Sampel diukur serapannya dengan ELISA reader pada panjang gelombang $405 \mathrm{~nm}$.

\section{Pengujian kontrol sampel ekstrak etanol daun} kersen (Muntingia calabura L.)

Ekstrak Untuk pengujian sampel ekstrak etanol daun kersen (Muntingia calabura L.) sebanyak $50 \mu \mathrm{L}$ dapar fosfat $(\mathrm{pH} 7)$, kemudian ditambahkan $25 \mu \mathrm{L}$ PNPG $(5 \mathrm{mM})$, lalu ditambahkan $10 \mu \mathrm{L}$ larutan sampel dari masingmasing seri konsentrasi yang telah dibuat yaitu 50 ppm, 100 ppm, 150 ppm, 200 ppm, dan 250 ppm. Kemudian kedalam sampel ditambahkan $25 \mu \mathrm{L}$ larutan dapar fosfat ( $\mathrm{pH} 7$ ), lalu diinkubasi selama 30 menit pada suhu $37^{\circ} \mathrm{C}$. Reaksi dihentikan dengan menambahkan $100 \mu \mathrm{L}$ larutan natrium karbonat 0,2 M. Sampel diukur serapannya dengan ELISA reader pada panjang gelombang $405 \mathrm{~nm}$.

\section{Analisis data}

Ekstrak Persentase inhibisi dari $\alpha$ glukosidase didapatkan dengan formula berikut (Febriyani 2014, h. 7):

$$
\% \text { inhibisi }=\frac{B-S}{B} \times 100 \%
$$

Ket:

$\mathrm{B}=$ Selisih absorbansi blanko dengan absorbansi kontrol blanko

$\mathrm{S}=$ Selisih absorbansi sampel dengan absorbansi kontrol sampel

Nilai IC $_{50}$ (Inhibitor Concentration 50) ditentukan dengan cara membuat kurva antara persen penghambatan versus konsentrasi atau nilai probit versus log konsentrasi hingga didapatkan persamaan regresinya. Dari persamaan regresi tersebut dapat ditentukan besaran konsentrasi ekstrak yang memiliki kemampuan penghambatan terhadap aktivitas enzim alpha glukosidase sebesar $50 \%$. Melalui persamaan regresi linear, $y=a+b x, x$ adalah log konsentrasi $\mathrm{n}$ sampel dan y adalah nilai probit, maka nilai $\mathrm{IC}_{50}$ dapat dihitung menggunakan menggunakan rumus:

$$
\mathrm{IC}_{50}=\frac{5-a}{b}
$$

Keterangan:

$\mathrm{a}=$ Intersept dari plot sumbu $\mathrm{x}$ dan $\mathrm{y}$

$\mathrm{b}=$ Slope plot sumbu $\mathrm{x}$ dan $\mathrm{y}$

$\mathrm{y}=$ Dinyatakan sebesar 5

$\mathrm{x}=$ Nilai $\mathrm{IC}_{50}$
Tingkat kekuatan suatu zat dalam menghambat enzim $\alpha$-glukosidase dapat dilihat pada Tabel 1.

Tabel 1. Tingkat kekuatan inhibisi terhadap enzim $\alpha$-glukosidase

\begin{tabular}{ll}
\hline \multicolumn{1}{c}{ Intensitas } & Nilai IC $_{50}$ \\
\hline Sangat aktif & $\mathrm{IC}_{50} \leq 25 \mu \mathrm{g} / \mathrm{mL}$ \\
Aktif & $25 \mu \mathrm{g} / \mathrm{mL}<\mathrm{IC}_{50} \leq 50$ \\
& $\mu \mathrm{g} / \mathrm{mL}$ \\
Kurang Aktif & $50 \mu \mathrm{g} / \mathrm{mL}<\mathrm{IC}_{50} \leq 100$ \\
Tidak Aktif & $\mu \mathrm{g} / \mathrm{mL}$ \\
(Widiyarti, Susilowati, \& Aspiyanto 2012, h. 37)
\end{tabular}

\section{HASIL DAN PEMBAHASAN}

Pada penelitian ini dilakukan uji aktivitas ekstrak etanol daun kersen (Muntingia calabura L.) sebagai inhibitor enzim $\alpha$-glukosidase. Tahapan awal yang dilakukan pada penelitian ini ialah dengan pembuatan ekstrak daun kersen (Muntingia calabura L.) menggunakan metode ekstraksi cara dingin yaitu maserasi. Hasil yang diperoleh dari metode ekstraksi daun kersen (Muntingia calabura L.) dapat dilihat pada Tabel 2.

Tabel 2. Persen rendamen ekstrak etanol daun kersen (Muntingia calabura L)

\begin{tabular}{ccccc}
\hline $\begin{array}{c}\text { Jenis } \\
\text { pelarut }\end{array}$ & $\begin{array}{c}\text { Volume } \\
\text { Pelarut } \\
(\mathbf{m L})\end{array}$ & $\begin{array}{c}\text { Berat } \\
\text { Sampel } \\
\text { Kering } \\
\mathbf{( g )}\end{array}$ & $\begin{array}{c}\text { Berat } \\
\text { Ekstrak } \\
\mathbf{( g )}\end{array}$ & $\begin{array}{c}\text { Persen } \\
\text { Rendamen } \\
\mathbf{( \% )}\end{array}$ \\
\hline $\begin{array}{c}\text { Etanol } \\
96 \%\end{array}$ & 2250 & 50 & 7,93 & 15,86 \\
\hline
\end{tabular}

Pemilihan metode ekstraksi maserasi pengerjaannya lebih aman untuk semua metabolit sekunder termasuk yang tidak tahan terhadap pemanasan proses dilakukan dengan cara diulang sebanyak tiga kali dan disimpan dalam lemari agar terhindar dari cahaya untuk mencegah terjadinya reaksi yang dikatalis cahaya atau perubahan warna (Hasanah, et al 2016). Pemilihan pelarut etanol ialah karena gugus $\mathrm{OH}$ dalam etanol membantu melarutkan molekul polar dan ion-ion dan gugus alkilnya $\mathrm{CH} 3 \mathrm{CH} 2-$ dapat mengikat bahan non-polar. Dengan demikian etanol dapat melarutkan baik non maupun polar (Yulianti 2014). Adapun ekstrak kental yang diperoleh yaitu 7,93 gram dengan persen rendamen yang diperoleh $15,86 \%$.

Pada pengujian aktivitas inhibitor enzim $\alpha$ glukosidase, ada enam jenis larutan yang diuji yaitu, larutan sampel ekstrak etanol daun kersen (Muntingia calabura L.), larutan kontrol sampel ekstrak etanol daun kersen (Muntingia calabura L.), larutan blanko, larutan kontrol blanko, larutan pembanding akarbose, dan larutan kontrol pembanding akarbose. Larutan sampel ekstrak etanol daun kersen (Muntingia calabura L.) dibuat dengan seri konsentrasi yaitu 50 ppm, 100 ppm, 150 
ppm, 200 ppm, dan 250 ppm. Sedangkan larutan pembanding akarbose dibuat dengan seri konsentrasi yaitu 50 ppm, 100 ppm, 150 ppm, 200 ppm, dan $250 \mathrm{ppm}$. Seri konsentrasi ini dibuat agar dapat digunakan untuk membuat persamaan regresi untuk menghitung $\mathrm{IC}_{50}$ yang merupakan konsentrasi yang mampu menghambat $50 \%$ aktivitas enzim $\alpha$ glukosidase.

Pada uji ini digunakan larutan dapar fosfat $\mathrm{pH}$ 7,0 dikarenakan enzim $\alpha$-glukosidase dapat bekerja pada $\mathrm{pH}$ tersebut. Uji ini dilakukan pada panjang gelombang $405 \mathrm{~nm}$ menggunakan ELISA reader. Suhu inkubasi yang digunakan ialah $37^{\circ} \mathrm{C}$ yang merupakan suhu optimum untuk enzim ini dapat bekerja. Setelah inkubasi maka dalam larutan uji ditambahkan natrium karbonat 0,2 $\mathrm{M}$ yang yang digunakan untuk menghentikan reaksi pada larutan uji.

Mekanisme kerja enzim $\alpha$-glukosidase akan menghidrolisis p-nitrofenil- $\alpha$-Dglukopiranosida menjadi glukosa dan p-nitrofenol yang berwarna kuning, (Desmiaty, et al 2014). Aktivitas enzim diukur berdasarkan hasil absorbansi $p$-nitrofenol yang terbentuk. Semakin tinggi intensitas warna kuning yang terbentuk maka semakin rendah kemampuan suatu sampel untuk menginhibisi enzim $\alpha$-glukosidase.

Hasil uji ekstrak etanol daun kersen (Muntingia calabura L) sebagai inhibitor enzim $\alpha$ glukosidase dapat dilihat pada Tabel 3.

Hasil uji akarbose sebagai inhibitor enzim $\alpha$-glukosidase dapat dilihat pada Tabel 4.

Tabel 3. Hasil pengukuran absorbansi sampel ekstrak etanol daun kersen (Muntingia calabura L.) sebagai inhibitor enzim $\alpha$-glukosidase

\begin{tabular}{|c|c|c|c|c|c|c|c|}
\hline \multirow{2}{*}{$\begin{array}{c}\text { Konsentrasi } \\
(\mu \mathrm{g} / \mathrm{mL})\end{array}$} & \multicolumn{4}{|c|}{ Absorbansi } & \multirow{2}{*}{$\%$ inhibisi } & \multirow{2}{*}{$\begin{array}{c}\mathrm{IC}_{50} \\
(\mu \mathrm{g} / \mathrm{mL})\end{array}$} & \multirow{2}{*}{$\begin{array}{c}\text { Kekuatan } \\
\text { inhibisi } \\
\text { enzim }\end{array}$} \\
\hline & Blanko & $\begin{array}{l}\text { Kontrol } \\
\text { Blanko }\end{array}$ & Sampel & $\begin{array}{l}\text { Kontrol } \\
\text { Sampel }\end{array}$ & & & \\
\hline 50 & & & 0,902 & 0,019 & 58,56 & & \\
\hline 100 & & & 0,621 & 0,030 & 72,26 & & \\
\hline 150 & 2,179 & 0,048 & 0,487 & 0,036 & 78,83 & 34,197 & Aktif \\
\hline 200 & & & 0,406 & 0,041 & 82,87 & & \\
\hline 250 & & & 0,328 & 0,047 & 86,81 & & \\
\hline
\end{tabular}

Tabel 4. Hasil pengukuran absorbansi pembanding akarbose sebagai inhibitor enzim $\alpha$-glukosidase

\begin{tabular}{cccccc}
\hline $\begin{array}{c}\text { Konsentrasi } \\
(\boldsymbol{\mu g} / \mathbf{m L})\end{array}$ & $\begin{array}{c}\text { Log } \\
\text { Konsentrasi }\end{array}$ & \% inhibisi & Probit & $\begin{array}{c}\text { Persamaan } \\
\text { Garis Linear }\end{array}$ & $(\mathbf{I C} \mathbf{5 0} \boldsymbol{\mu g} / \mathbf{m L})$ \\
\hline 50 & 1,6989 & 23,84 & 4,2852 & & \\
100 & 2 & 33,75 & 4,5825 & $\mathrm{y}=0,5916 \mathrm{x}+$ & 683,12 \\
150 & 2,1760 & 35,35 & 4,6205 & 3,3231 & $\mathrm{R} 2=0,9245$ \\
200 & 2,3010 & 36,63 & 4,6592 & & \\
250 & 2,3979 & 39,13 & 4,7239 & & \\
\hline
\end{tabular}

Sebagai pembanding digunakan akarbose yang diketahui merupakan salah satu senyawa yang memiliki aktivitas sebagai inhibitor $\alpha$-glukosidase. Dari pengujian yang dilakukan diperoleh nilai $\mathrm{IC}_{50}$ $34,197 \mu \mathrm{g} / \mathrm{mL}$. Tingkat kekuatan inhibisi terhadap enzim $\alpha$-glukosidase ialah sangat aktif jika $\mathrm{IC}_{50} \leq 25$ $\mu \mathrm{g} / \mathrm{mL}$, aktif jika $25 \mu \mathrm{g} / \mathrm{mL}<\mathrm{IC}_{50} \leq 50 \mu \mathrm{g} / \mathrm{mL}$, kurang aktif jika $50 \mu \mathrm{g} / \mathrm{mL}<\mathrm{IC}_{50} \leq 100 \mu \mathrm{g} / \mathrm{mL}$ dan tidak aktif jika $\mathrm{IC}_{50}>100 \mu \mathrm{g} / \mathrm{mL}$. Sehingga dapat diketahui bahwa ekstrak etanol daun kersen (Muntingia calabura L) dikategorikan aktif sebagai inhibitor enzim $\alpha$-glukosidase. Sedangkan akarbose yang digunakan sebagai kontrol positif memiliki nilai $\mathrm{IC}_{50} \quad 683,12 \mu \mathrm{g} / \mathrm{mL}$ sehingga dapat dikategorikan tidak aktif. Tingginya nilai $\mathrm{IC}_{50}$ pada kontrol positif disebabkan karena enzim yang digunakan berasal dari Saccharomyces cerevisiae yang diketahui merupakan enzim $\alpha$-glukosidase I mengenali struktur glikosil. Sedangkan akarbose merupakan inhibitor enzim $\alpha$-glukosidase yang memiliki struktur maltosil yang lebih dikenali oleh enzim $\alpha$-glukosidase II yang berasal dari mamalia (Kimura et al 2003).

\section{Kesimpulan}

Berdasarkan hasil yang diperoleh pada penelitian ini, dapat disimpulkan bahwa ekstrak etanol daun kersen (Muntingia calabura L.) memiliki aktivitas sebagai inhibitor enzim $\alpha$ glukosidase dengan $\mathrm{IC}_{50} \quad 34,197 \mu \mathrm{g} / \mathrm{mL}$ dan dapat dikategorikan aktif.

\section{Daftar Pustaka}

Apriyanti, E 2016,'Efek Ekstrak Etanol Daun Kersen (Muntingia calabura L.) terhadap Penghambatan Peningkatan Kadar Gula Darah Pada Tikus Putih Jantan Galur Wistar', Perpusnwu.web.id/karyailmiah/document 
Arum, YP, Supartono, \& Sudarmin 2012, 'Isolasi dan Uji Daya Antimikroba Ekstrak Daun Kersen (Muntingia calabura)', Journal UNNES, urnal MIPA, vol. 35, no. 2, pp 165-174, viewed 20 Desember 2016, http://journal.unnes.ac.id/sju/index.php/jm

Desmiaty, Y, Tambunan, RMarisi, \& Pithaloka, LDyah 2014, 'Uji Aktivitas Penghambatan Enzim $\alpha$-glukosidase serta Uji Mutu Ekstrak Etanol Batang Brotowali (Tinospora crispa L. Miers)', Jurnal Ilmu Kefarmasian Indonesia, vol. 12, no. 2, pp 232-238, viewed 18 Desember 2016, http://jifi.ffup.org/wpcontent/uploads/2015/11/232-237_yesi.pdf

Febrinda, AEarly, Astawan, M, Wesdiyati, T, \& Yuliana, NDewi 2013, 'Kapasitas Antioksidan dan Inhibitor Alpha Glukosidase Ekstrak Umbi Bawang Dayak', J Teknol dan Industri Pangan, $J P B$, vol. 24, no. 2, pp 161-167, viewed 28 Desember 2016. http://journal.jpb.ac.id/index.php/jtip

Febriyani, V 2014,' Uji Potensi Alfa Glukosidase dan Hipoglikemik Ekstrak Biji Mahoni (Swietenia Mahagoni Jacq) Sebaga Kandidat Obat Antidiabetes', Fakultas Kedokteran Hewan, Institut Pertanian Bogor

Hasanah, M, Andriani, N \& Noprizon 2016,'Perbandingan Aktivitas Antioksidan Esktrak Etanol Daun Kersen (Muntingia calabura L.) Haasil Ekstraksi Maserasi dan Refluks', SCIENTIA, viewed 12 Marete 2017,www.jurnalscientia.org/index.php/sc ientia/article/download /52/64

Hikmal, Alam, G, \& Mufidah 2015, 'Aktivitas Inhibitor Alpha Glukosidase Fungi Endofit MPD2 yang Diisolasi dari Tanaman Ongkea (Mezzetia parviflora Becc.)', JST Kesehatan, vol. 5, no. 1, pp97-102, viewed 18 Desember 2016, http://pasca.unhas.ac.id/jurnal/files

Krishnaveni, M \& Dhanalaksmi, R 2014, 'Qualitative and Quantitative Study of Phytochemicals in Muntingia Calabura L. Leaf And Fruit', WJPR, World Journal of Pharmaceutical Research, Vol. 3, No. 6, pp 1687-1696, viewed 18 Desember 2016, www.wjpr.net

Kimura et al 2003,'Two potent competitive Inhibitors Discriminating alpha glucosidase Family I From Family II', ELSEVIER, viewed 14 Maret 2017, https://www.ncbi.nlm.nih.gov/pubmed/15 063189.

Nurhasanah, N 2012, Isolasi Senyawa Antioksidan Ekstrak Metanol Daun Kersen (Muntingia calabura L), Fakultas Matematika dan Ilmu
Pengetahuan Alam, Universitas Jendral Achmad Yani.

Sukmawati, Masdiana Tahir, N. S. The Activity Test of Ethanol Extract in Hibiscus Leaves ( Hibiscus Tiliaceus L .) as the $\alpha$ Glucosidase Enzyme Inhibitor by Using. $J$. Glob. Pharma Technol. 11, 279-286 (2019).

Sugiwati, S, Setiasih, S, \& Afifah, E 2009, 'Antihyperglycemic Activity of The Mahkota Dewa (Phaleria macrocarpa (Scheff.) Boerl.) Leaf Extracts as an Alpha Glucosidase Inhibitor', Makara Kesehatan, vol. 13, no. 2, pp 74-78, viewed 18 Desember 2016 , Journal.ui.ac.id/index.php. 